\section{Skala, topologische}

C. Vidal ${ }^{1}$ und W.-R. Külpmann ${ }^{2}$

${ }^{1}$ Landeskriminalamt Niedersachsen, Dezernat 53 „Chemie“, Hannover, Deutschland

${ }^{2}$ Hannover, Deutschland

Englischer Begriff topological scale
Definition Oberbegriff für $>$ Nominalskala und $>$ Ordinalskala.

\section{Literatur}

DIN 55350, Teil 12 (1989) Begriffe der Qualitätssicherung und Statistik. Merkmalsbezogene Begriffe. Beuth-Verlag, Berlin 